\title{
POST-FLEDGING HABITAT SELECTION BY THE SLENDER-BILLED PARAKEET (ENICOGNATHUS LEPTORHYNCHUS) IN A FRAGMENTED AGRICULTURAL LANDSCAPE OF SOUTHERN CHILE
}

\author{
Ana Paula B. Carneiro ${ }^{1,5}$, Jaime E. Jiménez ${ }^{2,3}$, and Thomas H. White Jr. ${ }^{4}$ \\ ${ }^{1}$ Laboratorio de Vida Silvestre, Universidad de Los Lagos, Avenida Fuchslocher 1305, Osorno, Chile \\ ${ }^{2}$ Sub-Antarctic Biocultural Conservation Program, Department of Biology and Department of Philosophy and Religion Studies, \\ University of North Texas, Denton, TX 76203-5017 \\ ${ }^{3}$ Omora Ethnobotanical Park, Universidad de Magallanes, Puerto Williams, Chile \\ ${ }^{4}$ U.S. Fish and Wildlife Service, Puerto Rican Parrot Recovery Program, Box 1600, \\ Rio Grande, Puerto Rico 00745
}

\begin{abstract}
Despite the importance of the post-fledging period in avian population dynamics, little is known about habitat use during this life stage. We examined habitat selection by radio-tracked juvenile Slender-billed Parakeets (Enicognathus leptorhynchus) at multiple spatial scales in a fragmented agricultural landscape of southern Chile. Using home ranges versus study area (home-range selection) and locations versus combined home range (habitat-type selection), we based spatial analyses of habitat selection on the population level. Slender-billed Parakeets made similar habitat choices across the hierarchical levels examined, except for riparian and native second-growth forests, which they avoided at the level of overall home-range selection but used in proportion to availability at the level of habitat-type selection. Farmland and pastures with high densities of scattered mature trees were the only habitats positively selected at multiple spatial scales, adding to the increasing amount of literature highlighting the value of such trees for native fauna in highly modified areas. These trees appeared to be important for the birds during the post-fledging period as sites for feeding, perching, and roosting and to facilitate movement through open agricultural landscapes.
\end{abstract}

Key words: agricultural landscapes, habitat use, post-fledging, radio-tracking, Slender-billed Parakeet, Enicognathus leptorhynchus.

\section{Selección de Hábitat por Enicognathus leptorhynchus en un Paisaje Agrícola Fragmentado en el Sur de Chile Durante el Período Posterior al Abandono de los Nidos}

Resumen. A pesar de la importancia del período posterior al abandono de los nidos en la dinámica poblacional de las aves, poco se sabe sobre el uso de hábitats durante esta etapa. El propósito de este estudio fue examinar la selección de hábitats por juveniles de Enicognathus leptorhynchus, mediante radio-telemetría, a múltiples escalas espaciales en un paisaje agrícola fragmentado en el sur de Chile. Los análisis espaciales de selección se basaron en el ámbito de hogar versus el área de estudio (selección del ámbito de hogar) y en las localizaciones versus los ámbitos de hogar combinados (selección del hábitat) a nivel poblacional. La selección de hábitats por E. leptorhynchus fue similar para los distintos niveles jerárquicos propuestos en el presente estudio, excepto por las áreas ribereñas y los bosques nativos secundarios que fueron evitados cuando los ámbitos de hogar fueron comparados con el área de estudio, y fueron utilizadas de acuerdo a su disponibilidad cuando las localizaciones se compararon con los ámbitos de hogar combinados. Las matrices agrìcolas que tenían mayores densidades de árboles aislados fueron los únicos hábitats seleccionados positivamente en múltiples escalas espaciales, concordando con la creciente literatura que destaca la importancia de estos elementos para la fauna nativa en ambientes altamente modificados. Estos árboles parecen ser importantes para el período posterior al abandono de los nidos, ya que son usados como fuentes de alimentación, sitios para descansar y dormideros, y para facilitar el desplazamiento a través del paisaje.

\section{INTRODUCTION}

Animals are usually distributed nonuniformly through their range (Marzluff et al. 2004, Harvey et al. 2008). Often they use habitats according to a combination of factors including resource availability, life-history strategies, dispersal abilities, and predation risks (Luck 2002, Brandt and Cresswell 2008, Harvey et al. 2008). Hence, habitat selection results from a hierarchical process of behavioral responses involving a disproportionate use or avoidance of some habitat types in relation to their availability (Thomas and Taylor 2006, Aarts et al. 2008).

Manuscript received 5 July 2010; accepted 22 June 2011.

${ }^{5}$ E-mail: anap_bertoldi@yahoo.com.br

The Condor, Vol. 113, Number 1, pages 166-172. ISSN 0010-5422, electronic ISSN 1938-5422. @ 2012 by The Cooper Ornithological Society. All rights reserved. Please direct all requests for permission to photocopy or reproduce article content through the University of California Press's Rights and Permissions website, http://www.ucpressjournals.com/ reprintInfo.asp. DOI: 10.1525/cond.2011.100127 
Ideally, the most effective way to conserve animal populations is by protecting habitats upon which these populations depend (Petit et al. 1999, Brandt and Cresswell 2008, Lagory et al. 2009). To be effective, however, conservation requires the protection of critical resources through all life stages (Ciudad et al. 2009). Although juvenile survival and dispersal can have important effects on population dynamics, the post-fledging period is perhaps the least studied and least understood part of the avian life cycle (Kershner et al. 2004, Salinas-Melgoza and Renton 2007, Whittaker and Marzluff 2009). The few studies that have examined habitat use by juvenile birds during the post-fledging period suggest that habitat use is influenced mainly by food supply and foraging conditions (e.g., Ciudad et al. 2009, Mitchell et al. 2009).

Beyond the importance of understanding habitat requirements at various life stages, there is ample evidence that studies addressing only one spatial scale are inherently limited (Luck 2002, Beasley et al. 2007, Ciudad et al. 2009), because habitat-use patterns, particularly those in fragmented landscapes, are influenced by ecological processes occurring at multiple spatial scales (Li et al. 2006, White et al. 2006, Bayley and Thompson 2007, Manning et al. 2007, Vergara and Armesto 2009). Johnson (1980) suggested four levels of habitat selection associated with scale-dependent habitat use, reflecting resource use by species across multiple hierarchically nested spatial scales (Ciarniello et al. 2007, Lagory et al. 2009). These hierarchical orders of selection are defined as selection within the geographical range of the species (first order), selection of a home range by an individual or social group within the landscape (second order), selection of habitat types within the home range (third order), and selection of a specific resource, such as a nest site (fourth order) (Johnson 1980, Li et al. 2006, Ciarniello et al. 2007, Lagory et al. 2009). Therefore, optimal conservation strategies should consider habitat selection through all life stages and at multiple spatial scales.

Although multitudes of animal populations are declining worldwide because of anthropogenic destruction and alteration of their habitats (Petit et al. 1999, Virkkala et al. 2004, Carter et al. 2006), for many such species there is a lack of basic ecological information on which conservation measures might be based. For example, the Slender-billed Parakeet (Enicognathus leptorhynchus) is a medium-sized ( 300 g) psittacine endemic to southern Chile for which existing ecological information is both scant and anecdotal. Early reports indicate that the species was widely distributed through the temperate forests of Nothofagus (Philippi 1864, Hellmayr 1932, Goodall et al. 1957), which have been largely fragmented and degraded by humans for agriculture and livestock grazing (Echeverría et al. 2006, 2007).

Although the Slender-billed Parakeet is categorized as a vulnerable species in southern Chile (Servicio Agrícola y Ganadero 1998), its basic ecology during the post-fledging period and attributes such as home-range size, habitat-use patterns, and habitat selection have remained unknown. Despite being legally protected in Chile, the Slender-billed Parakeet is nevertheless highly persecuted by farmers because of its perceived damage to agricultural crops and orchards (Carneiro 2010). The purpose of our study was to examine habitat selection by radio-tracked juvenile Slender-billed Parakeets at multiple spatial scales in a fragmented agricultural landscape of southern Chile. We based our analyses of habitat selection on the population-level second and third hierarchical orders proposed by Johnson (1980). Our fundamental objective was to obtain baseline ecological data on a bird heretofore poorly known, data that could be a base not only for recommendations of specific conservation measures but also for speciesspecific research priorities.

\section{METHODS}

\section{STUDY AREA}

We studied Slender-billed Parakeets within $520 \mathrm{~km}^{2}$ of fragmented landscape devoted to agriculture and livestock grazing in the central valley of the Lakes Region, southern Chile, $12 \mathrm{~km}$ south of the city of Osorno $\left(40^{\circ} 55^{\prime} \mathrm{S}, 73^{\circ} 35^{\prime} \mathrm{W}\right)$. The climate is cool wet-temperate (sensu Holdridge 1967) with a strong oceanic influence (Echeverría et al. 2007). Rainfall is evenly distributed throughout the year, with a slight reduction during the austral summer (December- February). Average yearly precipitation is $1383 \mathrm{~mm}$, and the mean temperature is $11.4^{\circ} \mathrm{C}$ (Luebert and Pliscoff 2006).

Historically, the region was covered by continuous deciduous lowland forest dominated by the trees Nothofagus obliqua, Laurelia sempervirens, and Persea lingue (Donoso 1993, Luebert and Pliscoff 2006). However, intensive logging and anthropogenic fires have shaped the landscape for at least the past 100-150 years (Castellón and Sieving 2006, Echeverría et al. 2007, Vergara and Armesto 2009). The current landscape is a mosaic of small patches of secondary forest and plantations of exotic trees surrounded by extensive areas of farmland and pastures (Fig. 1) with numerous mature $N$. obliqua and L. sempervirens scattered throughout.

\section{NEST MONITORING AND TELEMETRY \\ INSTRUMENTATION}

During the breeding season of 2008-2009 (i.e., OctoberJanuary), we located Slender-billed Parakeet nests within the study area by direct observation and with information on nest locations supplied by local residents, some of whom were former nest poachers. We periodically monitored nestlings' development and attached radio transmitters generally within a week before chicks fledged. We attached transmitters to the two heaviest chicks in each brood to minimize the ratio of transmitter to body weight. We used Holohil SB-2C radio transmitters that broadcast for approximately 6 months 
and weighed $6 \mathrm{~g}$ ( $\sim 2 \%$ of adult parakeets' body weight). We fitted 18 Slender-billed Parakeets from ten different nests with transmitters.

\section{RADIO-TRACKING}

Radio-tracking of juvenile birds began immediately after fledging (i.e., 21 January-6 February) and continued until death of the bird $(n=4)$ or disappearance of the radio signal from the study area. We tracked juveniles from the ground four or five times per week during daylight hours. We estimated their locations by triangulation with a three-element hand-held antenna and a Telonics TR-2 receiver from many random points (marked with a hand-held GPS) across the study area at random times. We determined transmitters' bearings with the loudest signal and a Suunto hand-held compass (White et al. 2005b, Ripper et al. 2007). To minimize potential errors due to the parakeets' movements, we used only bearings recorded within 20 min of each other (Beasley et al. 2007), and, to minimize error polygons, most bearings were from locations with angular differences between $45^{\circ}$ and $135^{\circ}$ (Samuel and Fuller 1994, Jiménez 2007). Moreover, to reduce potential error further and to validate locations estimated by telemetry and associated habitat types, we confirmed locations frequently by visual and/or auditory contact. The generally open and level terrain of the study area facilitated homing and visual contact with instrumented parakeets. To reduce temporal autocorrelation of data points, we separated successive locations of individuals by at least $3 \mathrm{hr}$ (White et al. 2005a, Hough and Dieter 2009). When doing ground-based telemetry we also searched for signals beyond the delineated study area in an effort to compensate for the limitations of our telemetry system (i.e., 1.5 - to 2 -km reception radius). Furthermore, to detect whether parakeets used areas beyond the reception of the ground-based method, we twice flew an aircraft equipped for telemetry over the general area.

\section{STATISTICAL ANALYSES}

Home-range analysis. We estimated all telemetry locations meeting aforementioned criteria with LOAS (Location of a Signal 3.0.4; Ecological Software Solutions, Hegymagas, Hungary). We then entered nest sites, telemetry locations, and exact locations (e.g., direct observations) into Biotas $1.03 \alpha$ (Ecological Software Solutions) to estimate the home ranges of radiotagged birds. Because fledgling psittacines are highly dependent upon their parents for an extended period (Snyder et al. 1986, Myers and Vaughan 2004, Salinas-Melgoza and Renton 2007), in effect we report post-fledging habitat selection by family groups. Accordingly, we pooled data for siblings to generate family groups' home ranges, as individuals' ranges were not independent. For each family group we used a 95\% fixed-kernel estimator to estimate home-range size and contours. We chose the fixed-kernel estimator because it may provide a more accurate representation of a home range than do other estimators (Powell 2000, White et al. 2006, Ripper et al. 2007).
Population-level habitat use and selection. We assessed habitat selection on the basis of the second and third hierarchical orders adapted from Johnson (1980). To evaluate population-level second-order selection (home-range selection), we compared the proportion of habitat types for all home ranges to the habitat composition of the overall study area (home ranges versus study area). For third-order selection (habitat-type selection), we compared the proportion of telemetry locations within each habitat type with the corresponding proportion of habitat available within the combined home range (locations versus combined home range). We defined the study area (i.e., overall availability) as a 99\% fixed-kernel estimate of all locations plus a buffer equal to the mean radius of all $95 \%$ fixed-kernel home ranges of family groups (Fig. 1). To accommodate inherent landscape variability and the parakeets' movements, we used virtually all locations (99\%) plus a buffer to maximize the area available. We did this because, on the basis of aerial telemetry, we found that parakeets could range up to $16 \mathrm{~km}$ from our central radio-tracking point (Carneiro 2010).

To assess habitat selection, we used Bonferroni confidence intervals (Neu et al. 1974), which employ chi-squared tests followed by calculation of simultaneous $95 \%$ confidence intervals for the observed proportion of use within each habitat type, in which we adjusted $\alpha$ for the comparisons of observed and expected values (i.e., Bonferroni intervals) (Slattery and Alisauskas 2007). We selected the technique of Neu et al. (1974) instead of the approach of Aebischer et al. (1993) because we were interested in assessing habitat use at the population level, that is, animals were not uniquely identified and availability was defined at the population level. We considered habitat types

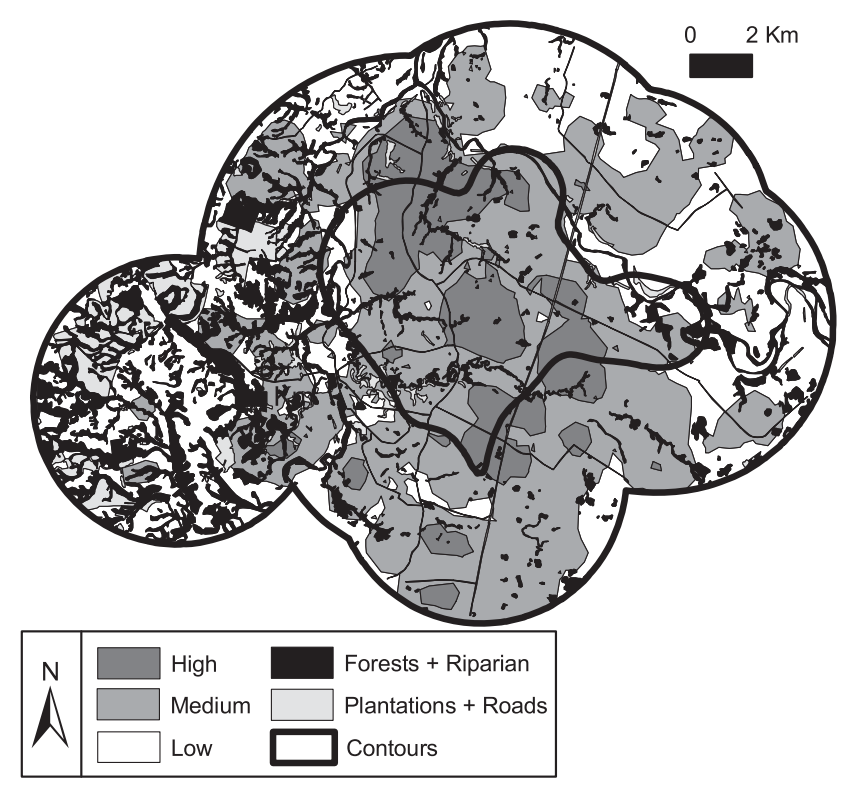

FIGURE 1. Study area and land-use covers: farmlands and pastures with the density of isolated trees (high, medium, or low), plantations of exotic trees, roads, and native forests with riparian strips. Outer contour represents the overall study area. Inner contour represents combined $95 \%$ fixed-kernel home ranges. 
TABLE 1. Home range and habitat selection of the Slender-billed Parakeet (Enicognathus leptorhynchus). Proportions of observed and expected use that differed significantly $(P<0.05)$ are shown in italics.

\begin{tabular}{|c|c|c|c|c|c|c|}
\hline Land use & Area (ha) $(\%)$ & Observed & Expected & Lower $\mathrm{CI}^{\mathrm{a}}$ & Upper CI & Selection $^{\mathrm{b}}$ \\
\hline \multicolumn{7}{|c|}{ Habitat composition of home range versus overall study area (second-order selection) } \\
\hline \multicolumn{7}{|l|}{ Farmland $^{\mathrm{c}}$} \\
\hline High & $3672.0(10.9)$ & 0.331 & 0.109 & 0.234 & 0.428 & + \\
\hline Medium & $12778.1(38.1)$ & 0.490 & 0.381 & 0.451 & 0.594 & + \\
\hline Low & $10516.9(31.3)$ & 0.082 & 0.313 & -0.028 & 0.138 & - \\
\hline Plantations and roads & $1637.4(4.9)$ & 0.021 & 0.049 & 0.020 & 0.050 & 0 \\
\hline Forests and riparian & $4953.1(14.8)$ & 0.076 & 0.148 & 0.021 & 0.131 & - \\
\hline \multicolumn{7}{|c|}{ Locations versus combined home ranges (third-order selection) } \\
\hline \multicolumn{7}{|c|}{ Farmland } \\
\hline High & $2245.1(33.1)$ & 0.596 & 0.331 & 0.495 & 0.698 & + \\
\hline Medium & $3324.7(49.0)$ & 0.276 & 0.490 & 0.183 & 0.368 & - \\
\hline Low & $553.5(8.2)$ & 0.019 & 0.083 & -0.009 & 0.048 & - \\
\hline Plantations and roads & $140.5(2.1)$ & 0.013 & 0.019 & -0.010 & 0.036 & 0 \\
\hline Forests and riparian & $515.8(7.6)$ & 0.096 & 0.076 & 0.035 & 0.157 & 0 \\
\hline
\end{tabular}

as selected or avoided if values of expected habitat use were below or above Bonferroni intervals for proportional habitat use, respectively (Slattery and Alisauskas 2007).

The highly social and flocking habits of the Slender-billed Parakeet resulted in a lack of independence of individuals, which precluded and invalidated analyses of habitat selection at the level of the individual. Instead, we pooled individual parakeets' point locations. This was justified by similarities in habitat use and availability patterns that accrued from the dominance $(80.3 \%$, Table 1$)$ of farmland and pastures within the study area (Hough and Dieter 2009) and because all birds were radio-tagged within the same general area (Carneiro 2010).

Land cover. We digitized all land-use covers within the study area from georeferenced QuickBird satellite images available from GoogleEarth Pro software. Given the high spatial resolution of these images, we could map and digitize patches with a resolution of 0.06 ha (e.g., a large tree). To cross-validate classifications, we also verified numerous points and polygons from the resulting map in the field with a global positioning system (GPS). We defined land-use covers for the combined home range with the clip tool in ArcGIS to extract the land-use information contained in the largest polygon. We used ArcGIS 9 (ESRI 2008) for all spatial analyses.

To determine the density of scattered mature trees, we digitized isolated trees as points and classified all areas into one of three density categories with the Point Density function in the Spatial Analyst tool. These categories were high $(>257$ trees $\left.\mathrm{km}^{-2}\right)$, medium $\left(128-257\right.$ trees $\left.\mathrm{km}^{-2}\right)$, and low $(<128$ trees $\mathrm{km}^{-2}$ ). For subsequent habitat-selection analyses, we converted the final raster image to a vector file with 3D Analyst.
We identified seven distinctive land-use covers: plantations of exotic trees (henceforth referred to as "plantations"), riparian strips (riparian), roads, native secondary forests (forests), farmland and pastures with a high density of isolated trees (high), farmland and pastures with a medium density of trees (medium), and farmland and pastures with a low density of trees (low) (Fig. 1). To remove the bias inherent in chi-squared tests when one or more habitats have expected values of $<5$, we combined some land-use covers. We combined forests with riparian because the latter generally included native vegetation, and we combined roads and plantations, areas associated with more intense human presence and activities, a factor that could affect the Slender-billed Parakeet's habitat selection.

\section{RESULTS}

\section{HOME RANGE AND MOVEMENTS}

Of the 18 Slender-billed Parakeets we radio-tagged, 12 yielded data sufficient for population-level analyses. Six birds were not used in the analyses either because they died soon after fledging or because of rapid loss of the radio signal. From 21 January through 11 May 2009 we tracked four individual birds and four pairs of siblings. Duration of tracking ranged from 8 to 95 days, with a mean of 67 days. To evaluate population-level home ranges, we used a total of 159 locations from 12 juvenile Slenderbilled Parakeets ( $\bar{x}=21$ locations per family, range 13-33).

Individuals' and family groups' $95 \%$ fixed-kernel home ranges ranged from 147.2 to $8451.1 \mathrm{ha}(\bar{x} \pm \mathrm{SE}, 4402.0 \pm 1116.0$ ha, $n=8)$. Because these home ranges increased through the study 
period $\left(R^{2}=0.21, P<0.001\right)$, our estimates of home-range size are therefore conservative, as longer sampling would likely have revealed ranges larger than those we report.

\section{HABITAT SELECTION}

At the scale of the home range, second-order selection, habitat use was nonrandom $\left(\chi_{4}^{2}=394.57, P<0.001\right)$. The parakeets used farmland and pastures with high and medium densities of scattered mature trees more than expected (Table 1) and avoided areas with low densities of mature trees as well as secondary forests and riparian strips. They used plantations and roads in proportion to their availability (Table 1). At the third-order selection scale, habitat choice was also nonrandom $\left(\chi_{4}^{2}=56.12, P<0.001\right)$ and patterns were similar to that of second-order selection, with areas containing high densities of scattered mature trees used more than expected, although areas with medium to low densities of trees were avoided. Plantations and roads were also used in proportion to their availability (Table 1).

\section{DISCUSSION}

We identified distinct patterns of the Slender-billed Parakeet's movement, and these were related with time since fledging. The radial distance from the nest sites, as well as social behaviors such as flock integration, increased over time. An increase with time in young psittacines' average distance from nest sites has also been reported by other authors (e.g., Myers and Vaughan 2004, Salinas-Melgoza and Renton 2007). We found Slenderbilled Parakeets making limited movements within a $1-\mathrm{km}$ radius of the nest site during the first $4-5$ days after fledging, except for three fledglings that left the nest site's vicinity almost immediately. One parakeet showed high fidelity to the nest site for 5 days, remaining within a 300-m radius of the nest tree. Fledglings spent most of their first 2 weeks interacting only with their own family group. By the fledglings' third week, family groups began integrating into larger flocks, as reported also by Salinas-Melgoza and Renton (2007) for the Lilaccrowned Parrot (Amazona finschi) in Mexico.

Farmland and pastures with high densities of mature trees were the only habitat the Slender-billed Parakeet positively selected at multiple spatial scales, adding to the growing literature highlighting the value of scattered trees for native fauna in highly modified landscapes (e.g., Fischer and Lindenmayer 2002, Manning et al. 2006a, Gibbons et al. 2008, Koch et al. 2009). Not only are remnant mature trees of $N$. obliqua currently the Slender-billed Parakeet's primary nesting sites within the study area (Carneiro 2010), such trees may also facilitate birds' movement through open agricultural landscapes by providing sites for feeding, resting and roosting as well as refuge from predators (Fischer and Lindenmayer 2002, Gibbons and Boak 2002, Fischer et al. 2005, Manning and Lindenmayer 2009). Mitchell et al. (2009) also reported that extensive open areas with low densities of trees and shrubs inhibited movements of and limited foraging opportunities for fledgling and juvenile songbirds in boreal forests of Canada.

The Slender-billed Parakeet's positive selection of areas with higher densities of trees may present some adaptive advantages. For example, clumps of scattered mature trees are likely the first indication of potential feeding sites. Higher densities of such trees should increase chances of the parakeets' finding available food sources. Moreover, during the first 2 weeks after fledging, the parakeets' movements were limited within a $1-\mathrm{km}$ radius of the nest site. Accordingly, habitat selection immediately after fledging may also be an artifact of the adults' nest-site selection and neophyte fledglings' inherently limited vagility. This most likely explains the observed difference between second- and third-order selection with respect to areas of medium tree density. That is, parakeets nesting in areas with higher tree densities are also more likely to use such areas immediately after fledging. Indeed, in a parallel study we detected that the nest sites adult parakeets selected most frequently were those whose immediate surroundings provided ample opportunities for foraging as well as abundant sites for perching and roosting (Carneiro 2010). White et al. (2006) reported similar findings for Puerto Rican Parrots (A. vittata) nesting in montane rainforests.

Predation may also contribute to juveniles and family groups choosing habitats with higher tree densities during the post-fledging period. Because juveniles of many bird species are more susceptible to predation during the first weeks after fledging (Kershner et al. 2004, Myers and Vaughan 2004, Whittaker and Marzluff 2009), juveniles and family groups may choose those habitats that provide the greatest protection from predators (White et al. 2006, Ciudad et al. 2009). Although we documented the death of four $(22 \%)$ of the fledglings marked during the study, we were unable to obtain conclusive evidence of the cause(s) of mortality, such as predation. Within our study area, native secondary forest and pine plantations evidently provide the densest vegetative cover and protection. But our expectation of selection of these habitats over farmland and pastures was not met. Although we grouped pine plantations and roads for analysis, and most roads were characterized as open areas, we do not believe that this grouping masked effects of shelter associated with pine plantations, because roads represented only $0.6 \%$ of the study area, compared to $4.3 \%$ for pine plantations. Furthermore, road traffic may represent a high risk to birds foraging on or near the ground, as Slender-billed Parakeets often do (Carneiro 2010). In a study evaluating the importance of human-modified lands, Petit and Petit (2003) also reported that plantations of exotic pines had virtually no habitat value for conservation of neotropical birds. In Australia, Manning et al. $(2006 b, 2007)$ found a similar pattern for the Superb Parrot (Polytelis swainsonii), which was more abundant in highly modified open woodlands than in dense monocultures. 
Although we found radiotelemetry essential for monitoring parakeet movements during the post-fledging period, logistical and resource constraints restricted our sampling to a relatively small area and few individuals. Accordingly, our results should be interpreted as preliminary.

The Slender-billed Parakeet, like other psittacids, is intelligent and adaptable, characteristics that likely promote its persistence in dynamic landscapes (MacNally and Horrocks 2000, Marsden et al. 2000, Evans et al. 2005, Nunes and Galetti 2007). These characteristics may facilitate the adaptation of foraging behavior to include most available resources within a given area. However, the Slender-billed Parakeet's persistence may also be conditional on the continued availability of abundant scattered mature trees throughout the existing agricultural matrix, as both sites for nests and sources of food (we frequently saw Slender-billed Parakeets in Nothofagus obliqua, feeding on its seeds). The current lack of protection for scattered mature trees and their rapid and continuous loss via anthropogenic alterations, combined with poor regeneration (Echeverría et al. 2006, 2007), threatens the persistence of Slender-billed Parakeets in fragmented landscapes of southern Chile, as also reported by Manning et al. (2004, 2006b) for the Superb Parrot in Australia.

\section{ACKNOWLEDGMENTS}

This study was supported by the Laboratorio de Vida Silvestre at Universidad de Los Lagos, the United States Fish and Wildlife Service-Puerto Rican Parrot Recovery Program, Parrots International, Amigos de Las Aves USA, International Conure Association, Global Environment Fund-Sistema Regional de Áreas Protegidas, and Tony Pittman. We thank Mario Keim, Marcelo Keim, Marcelo Hott, Jorge Hott, Silvia Hott, and Guillermo Hott, who allowed us to work on their properties, and Claire Foster, Marialisa Laurelia, and Patricio Sáez, who helped monitor the parakeets. Donald Brightsmith, Philip Unitt, and an anonymous reviewer provided valuable suggestions for improving the manuscript. Parakeet handling and instrumentation was authorized by permit 5484 from the Servicio Agrícola y Ganadero. Use of trade names does not imply endorsement by Universidad de Los Lagos or the U.S. Fish and Wildlife Service.

\section{LITERATURE CITED}

Aarts, G., M. MacKenzie, B. McConnell, M. Fedak, and J. MAtTHIOPOULOS. 2008. Estimating space-use and habitat preference from wildlife telemetry data. Ecography 31:140-160.

Aebischer, N. J., P. A. Robertson, And R. E. Kenward. 1993. Compositional analysis of habitat use from animal radio-tracking data. Ecology 74:1313-1325.

BAyley, J. W., AND F. R. ThOmPson. 2007. Multiscale nest-site selection by Black-capped Vireos. Journal of Wildlife Management 71:828-836.

Beasley, J. C., T. L. DeVault, M. I. Retamosa, And O. E. Rhodes JR. 2007. A hierarchical analysis of habitat selection by raccoons in northern Indiana. Journal of Wildlife Management 71:1125-1133.

BRANDT, M. J., AND W. CResswell. 2008. Breeding behavior, home range and habitat selection in Rock Firefinches Lagonosticta sanguinodorsalis in the wet and dry season in central Nigeria. Ibis 150:495-507.
CARneiro, A. P. B. 2010. Uso espacial de paisajes fragmentados por el Choroy (Enicognathus leptorhynchus) en el sur de Chile. M.Sc. thesis, Universidad de Los Lagos, Osorno, Chile.

Carter, G. M., E. D. Stolen, And D. R. Breininger. 2006. A rapid approach to modeling species-habitat relationships. Biological Conservation 127:237-244.

CAstellón, T. D., AND K. E. Sieving. 2006. Landscape history, fragmentation, and patch occupancy: models for a forest bird with limited dispersal. Ecological Applications 16:2223-2234.

Ciarniello, L. M., M. S. Boyce, D. R. Seip, and D. C. Heard. 2007. Grizzly bear habitat selection is scale dependent. Ecological Applications 17:1424-1440.

Ciudad, C., H. Robles, and E. Matthysen. 2009. Post-fledging habitat selection of juvenile Middle Spotted Woodpeckers: a multi-scale approach. Ecography 32:676-682.

Donoso, C. 1993. Bosques templados de Chile y Argentina, variación, estructura y dinámica. Editorial Universitaria, Santiago.

Echeverría, C., D. A. Coomes, A. C. Newton, J. Salas, J. M. REY, AND A. LARA. 2006. Rapid fragmentation and deforestation of Chilean temperate forests. Biological Conservation 130:481-494.

Echeverría, C., A. C. Newton, A. Lara, J. M. R. Benayas, and D. A. CoOMES. 2007. Impacts of forest fragmentation on species composition and forest structure in the temperate landscape of southern Chile. Global Ecology and Biogeography 16:426-439.

ESRI. 2008. ArcGIS 9. Environmental Systems Research Institute, Inc., Redlands, CA.

Evans, B. E. I., J. Ashley, And S. J. Marsden. 2005. Abundance, habitat use, and movements of Blue-winged Macaws (Primolius maracana) and other parrots in and around an Atlantic forest reserve. Wilson Bulletin 117:154-164.

FisCHER, J., AND D. B. LindENMAYER. 2002. The conservation value of paddock trees for birds in a variegated landscape in southern New South Wales. 2. Paddock trees as stepping stones. Biodiversity and Conservation 11:833-849.

Fischer J., I. FAzeY, R. BieSE, AND D. B. LindenMaYer. 2005. Making the matrix matter: challenges in Australian grazing landscapes. Biodiversity and Conservation 14:561-578.

GiBBOns, P., AND M. BOAK. 2002. The value of paddock trees for regional conservation in an agricultural landscape. Ecological Management and Restoration 3:205-210.

Gibbons, P., D. B. Lindenmayer, J. Fischer, A. D. Manning, A. Weinberg, J. Seddon, P. Ryan, and G. Barrett. 2008. The future of scattered trees in agricultural landscapes. Conservation Biology 22:1309-1319.

Goodall, J. D., A. W. Johnson, And R. A. PhiLipPI. 1957. Las aves de Chile, su conocimiento y sus costumbres, vol. 1 and supplement. Platt Establecimientos Gráficos S.A., Buenos Aires.

Harvey, V., S. D. Côté, And M. O. Hammill. 2008. The ecology of 3-D space use in a sexually dimorphic mammal. Ecography 31:371-380.

Hellmayr, C. E. 1932. The birds of Chile. Field Museum of Natural History Press, Chicago.

HoldRIDGE, L. R. 1967. Life zone ecology. Tropical Science Center, San Jose, Costa Rica.

Hough, M. J., AND C. D. Dieter. 2009. Home range and habitat use of northern flying squirrels in the Black Hills, South Dakota. American Midland Naturalist 162:112-124.

JIMÉNEZ, J. E. 2007. Ecology of a coastal population of the critically endangered Darwin's fox (Pseudalopex fulvipes) on Chiloé Island, southern Chile. Journal of Zoology 271:63-77.

JoHNSON, D. H. 1980. The comparison of usage and availability measurements for evaluating resource preference. Ecology $61: 65-71$. 
Kershner, E. L., J. W. Walk, and R. E. Warner. 2004. Postfledging movements and survival of juvenile Eastern Meadowlarks (Sturnella magna) in Illinois. Auk 121:1146-1154.

Koch, A. J., S. A. MunKs, AND C. SPEnCER. 2009. Bird use of native trees retained in young eucalypt plantations: species richness and use of hollows. Wildlife Research 36:581-591.

Lagory, K. E., L. J. Walston, C. Goulet, R. A. Van Lonkhuyzen, S. NAJJAR, AND C. ANDREWS. 2009. An examination of scaledependent resource use by eastern hognose snakes in southcentral New Hampshire. Journal of Wildlife Management 73:1387-1393.

Li, X. H., D. M. Li, Z. J. MA, AND D. C. Schneider. 2006. Nest site use by Crested Ibis: dependence of a multifactor model on spatial scale. Landscape Ecology 21:1207-1216.

LUCK, G. W. 2002. The habitat requirements of the Rufous Treecreeper (Climacteris rufa). 1. Preferential habitat use demonstrated at multiple spatial scales. Biological Conservation 105:383-394.

Luebert, F., AND P. Pliscoff. 2006. Sinopsis bioclimática y vegetacional de Chile. Editorial Universitaria, Santiago.

MacNally, R., AND G. Horrocks. 2000. Landscape-scale conservation of an endangered migrant: the Swift Parrot (Lathamus discolor) in its winter range. Biological Conservation 92:335-343.

Manning, A. D., D. B. Lindenmayer, And S. C. Barry. 2004. The conservation implications of bird reproduction in the agricultural "matrix": a case study of the vulnerable Superb Parrot of southeastern Australia. Biological Conservation 120:363-374.

Manning, A. D., ANd D. B. LindenMaYer. 2009. Paddock trees, parrots and agricultural production: an urgent need for large-scale, long-term restoration in south-eastern Australia. Ecological Management and Restoration 10:126-135.

Manning, A. D., J. Fischer, And D. B. Lindenmayer. 2006a. Scattered trees are keystone structures: implications for conservation. Biological Conservation 132:311-321.

Manning, A. D., D. B. Lindenmayer, S. C. Barry, and H. A. NiX. 2006b. Multi-scale site and landscape effects on the vulnerable Superb Parrot of south-eastern Australia during the breeding season. Landscape Ecology 21:1119-1133.

Manning, A. D., D. B. Lindenmayer, S. C. Barry, and H. A. Nix. 2007. Large-scale spatial and temporal dynamics of the vulnerable and highly mobile Superb Parrot. Journal of Biogeography 34:289-304.

Marsden, S. J., M. Whiffin, L. Sadgrove, and P. Guimaraes JR. 2000. Parrot populations and habitat use in and around two lowland Atlantic forest reserves, Brazil. Biological Conservation 96:209-217.

Marzluff, J. M., J. J. Millspaugh, P. Hurvitz, and M. S. Handcock. 2004. Relating resources to a probabilistic measure of space use: forest fragments and Steller's Jays. Ecology 85:1411-1427.

Mitchell, G. W., I. G. Warkentin, and P. D. Taylor [online]. 2009. Movement of juvenile songbirds in harvested boreal forest: assessing residency time and landscape connectivity. Avian Conservation and Ecology 4(1): 5. http://www.ace-eco.org/ vol4/iss1/art5/,

Myers, M. C., AND C. Vaughan. 2004. Movement and behavior of Scarlet Macaws (Ara macao) during the post-fledging dependence period: implications for in situ versus ex situ management. Biological Conservation 118:411-420.
Neu, C. W., C. R. Byers, And J. M. Peek. 1974. A technique for analysis of utilization-availability data. Journal of Wildlife Management 38:541-545.

Nunes, F. C., AND M. Galetti. 2007. Use of forest fragments by Blue-winged Macaws (Primolius maracana) within a fragmented landscape. Biodiversity and Conservation 16:953-967.

Petit, L. J., AND D. R. Petit. 2003. Evaluating the importance of human-modified lands for neotropical bird conservation. Conservation Biology 17:687-694.

Petit, L. J., D. R. Petit, D. G. Christian, and H. D. W. Powell. 1999. Bird communities of natural and modified habitats in Panama. Ecography 22:292-304.

PhilipPI, R. A. 1864. Catálogo de las aves chilenas con su distribución geográfica. Investigaciones Zoológicas Chilenas 11:1-179.

Powell, R. A. 2000. Animal home ranges and territories and home range estimators, p. 65-103. In L. Boitani and T. K. Fuller [EDS.], Research techniques in animal ecology: controversies and consequences. Columbia University Press, New York.

RipPer, D., J. C. Bednarz, And D. E. Varland. 2007. Landscape use by Hairy Woodpeckers in managed forests of northwestern Washington. Journal of Wildlife Management 71:2612-2623.

Salinas-Melgoza, A., And K. Renton. 2007. Post-fledging survival and development of juvenile Lilac-crowned Parrots. Journal of Wildlife Management 71:43-50.

SAmuel, M. D., AND M. R. Fuller. 1994. Wildlife telemetry, p. 370-418. In T. A. Bookhout [ED.], Research and management techniques for wildlife and habitats. Wildlife Society, Bethesda, MD.

SERVicio Agrícola y GANADERo. 1998. Reglamento de la ley de caza, decreto supremo no. 5. Servicio Agrícola y Ganadero, Santiago.

Slattery, S. M., AND R. T. Alisauskas. 2007. Distribution and habitat use of Ross' and Lesser Snow Geese during late brood rearing. Journal of Wildlife Management 71:2230-2237.

SNyder, N. F. R., J. W. Wiley, AND C. B. KePler. 1986. The parrots of Luquillo: Natural history and conservation of the Puerto Rican Parrot. Western Foundation of Vertebrate Zoology, Los Angeles.

Thomas, D. L., AND E. J. TAYLOR. 2006. Study designs and tests for comparing resource use and availability II. Journal of Wildlife Management 70:324-336.

Vergara, P. M., AND J. J. ARmesto. 2009. Responses of Chilean forest birds to anthropogenic habitat fragmentation across spatial scales. Landscape Ecology 24:25-38.

VirkKala, R., M. LuOTO, AND K. Rainio. 2004. Effects of landscape composition on farmland and red-listed birds in boreal agricultural-forest mosaics. Ecography 27:273-284.

White, J. D., T. Gardali, F. R. Thompson III, and J. FaAborg. 2005a. Resource selection by juvenile Swainson's Thrushes during the post-fledging period. Condor 107:388-401.

White, T. H. JR,, J. A. Collazo, F. J. Vilella, and S. A. Guerrero. 2005b. Effects of Hurricane George on habitat use by captivereared Hispaniolan Parrots (Amazona ventralis) released in the Dominican Republic. Ornitología Neotropical 16:405-417.

White, T. H. JR., G. G. Brown, and J. A. Collazo [online]. 2006. Artificial cavities and nest site selection by Puerto Rican Parrots: a multiscale assessment. Avian Conservation and Ecology 1(3):5. $<$ http://www.ace-eco.org/vol1/iss3/art5>.

WhitTAKer, K. A., AND J. M. MARZluff. 2009. Species-specific survival and relative habitat use in an urban landscape during the post-fledging period. Auk 126:288-299. 